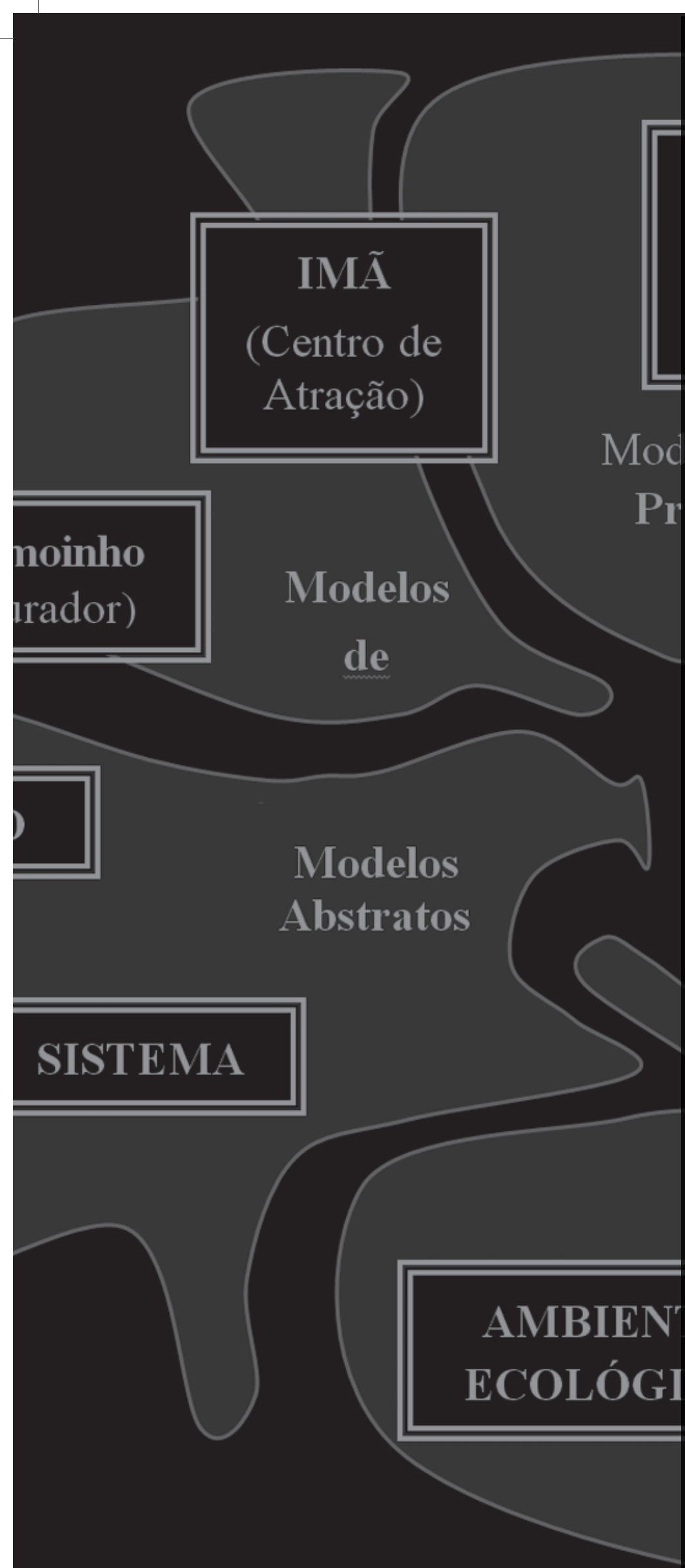

1. Doutor em História pela Universidade Federal Fluminense (UFF), professor adjunto nos cursos de graduação e pós-graduação em História da Universidade Federal Rural do Rio de Janeiro (UFRRJ), professor colaborador do Programa de Pós-graduação em História Comparada da Universidade Federal do Rio de Janeiro (UFRJ).
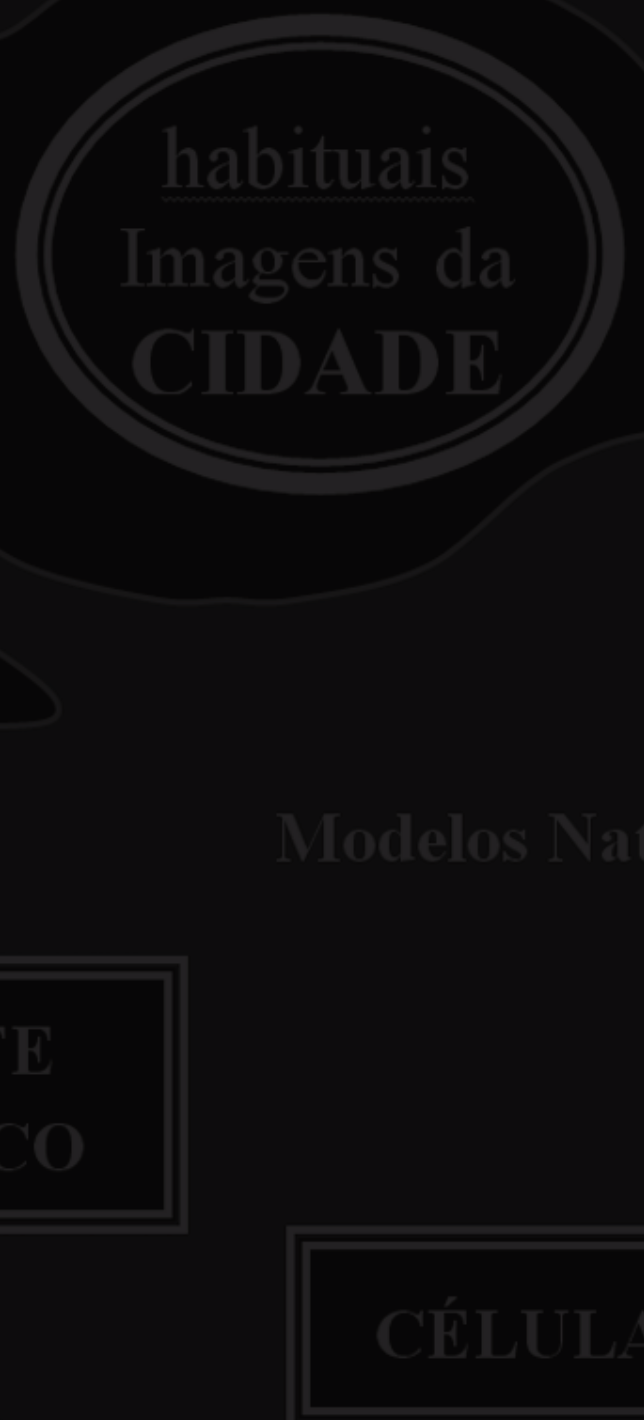


\title{
A CIDADE COMO FORMA ESPECÍFICA DE ORGANIZAÇÃO SOCIAL E SUAS IMAGENS NAS CIÊNCIAS HUMANAS
}

\author{
THE CITY AS SPECIFIC FORM OF SOCIAL ORGANIZATION \\ AND ITS IMAGES IN THE HUMAN SCIENCES
}

José D'Assunção Barros'

\begin{abstract}
Resumo
Esse artigo busca examinar a relação entre a utilização de imagens ou metáforas e a produção das ciências sociais e humanas sobre a cidade e sobre os fenômenos urbanos de modo geral. Após uma discussão inicial sobre a intensificação, nos séculos XIX e XX, de um pensamento científico sobre a cidade como forma específica de organização social, o artigo convida a repensar a relação entre os diferentes modos de conceber a cidade e as imagens de apoio utilizadas pelas Ciências Sociais e Humanas para esse fim. Nesse sentido, discute-se o uso das imagens na construção do conhecimento sobre a cidade (tais como as imagens do organismo, do artefato, do texto, do sistema, do ambiente ecológico, entre outras) em articulação com os vários modelos de cidade empregados para compreender o fenômeno urbano ao longo da reflexão do século XX nas Ciências Sociais e Humanas, incluindo a Sociologia, a Antropologia e a História.
\end{abstract}

Palavras-chave: cidade, história urbana, imagem.

\begin{abstract}
This article attempts to examine the relation between the use of images or metaphors and the production of studies about the City and the urbanistic phenomena in the social and human sciences. After an initial discussion about the intensification, in the XIX and XX centuries, of the scientific thought about the City as a specific form of social organization, the text invites to rethink the relation between the different conceptions about the city and the support images utilized by the social and human sciences to this finality. In this sense, it is discussed the usage of images in the construction of knowledge about the City - as the images of the organism, artifact, text, system, ecologic ambient, among others - in articulation with the several models employed to understand the City along the urbanistic thought of the twenty century in the Social and Human Sciences, including the Sociology, Anthropology and History.
\end{abstract}

Keywords: city, urban history, image. 


\section{As primeiras reflexões modernas sobre a cidade}

O século XX foi, de certa maneira, o "século da urbanização". Globalmente falando, é a partir daí que se pode dizer que a maior parte da população mundial passou a viver essencialmente em centros urbanos de diversos tipos. Essa ruptura com séculos e séculos de uma história humana, em que a maioria da população do planeta dedicava-se fundamentalmente a atividades agrícolas e em que a cidade devia ser vista muito mais como uma exceção do que como o ambiente mais familiar para os homens contribuiu naturalmente para que esse mesmo século $X X$ tenha assistido a uma grande eclosão de interesses nos vários campos do saber em estudar esse grande enigma e essa vasta trama de complexidade que é a cidade.

A História e as Ciências Humanas de um modo geral não poderiam ficar infensas a essas irresistíveis motivações em estudar, com base em várias perspectivas, a cidade como uma forma específica de organização social. Nessa linha, os historiadores e os cientistas sociais produziram, ao longo desse século, riquíssimos estudos e abordagens teóricas sobre a cidade que hoje, no alvorecer de um novo milênio, podem ser avaliadas em uma visão panorâmica.

Para começarmos a examinar as imagens que nos tempos recentes têm sido empregadas para a representação científica, historiográfica, sociológica e urbanística da cidade, há que se considerar, contudo, uma importante dívida (ou uma herança) do século XX em relação ao século XIX no que diz respeito aos estudos urbanos. De fato, não seria inapropriado dizer que a emergência da moderna reflexão sobre a cidade como "forma mais específica de organização social" remonta ao século XIX, seja na área da historiografia, seja no campo do pensamento sociológico. Não que nos tempos antigos, no Período Medieval e no início da Idade Moderna os homens tenham deixado de pensar a cidade e de expressar os seus anseios e expectativas sobre ela. A diferença, contudo, mostra-se particularmente em dois âmbitos que cumpre aqui ressaltar.

Por um lado, ainda não havia surgido, nos períodos anteriores, o interesse de desenvolver uma reflexão sobre o fenômeno urbano que estivesse mais firmemente ancorada em uma investigação sistemática, em métodos apropriados, em teorizações capazes de compreender a cidade e o fenômeno urbano em todas as suas dimensões possíveis. Isto é, não havia se manifestado ainda a motivação para transformar a reflexão sobre a cidade em um campo mais específico do saber.

Pensar e sentir a cidade fora muitas vezes uma tarefa dos poetas, dos cronistas e romancistas, dos teólogos, também dos arquitetos e dos filósofos, mas, neste último caso, sempre como um caminho para compreender problemas humanos mais gerais, para pensar os modelos ideais de organização do mundo político, para impor hierarquias sociais. Assim, pode-se dizer que, de outro lado, embora a cidade tenha sempre frequentado a reflexão de filósofos e pensadores dos mais diversos tipos, ela ainda não aparecia, como dissemos acima, como uma forma "mais específica" de organização social, contrastante em relação a outras, com um lugar próprio e problemas singulares que seriam só seus, com uma história à parte, embora integrada ao movimento mais geral da história humana. 
No século XIX, isso se modifica sensivelmente. Começam a surgir cada vez mais pensadores da sociedade (historiadores e também os sociólogos e antropólogos) preocupados em entender essa especificidade do "viver urbano", em decifrar a história desse viver, as suas mutações, as suas diferenças em relação a outros ambientes sociais e em compreender também a complexidade dos vários tipos de vida social que podiam ser abrigados nas diversas modalidades de formações urbanas. Essas preocupações iriam se intensificar ainda mais, conforme veremos, no século XX.

Por outro lado, também no campo mais específico do Urbanismo, começam a surgir, no século XIX, as primeiras obras preocupadas simultaneamente com a forma, a funcionalidade e seus desdobramentos sociais. Havia, é claro, os tratados renascentistas que, desde o século XV, propunham agir sobre a vida citadina por meio de uma ação sobre o espaço urbano que considerasse as suas necessidades econômicas e sociais, e aqui, nas teorizações desses arquitetos renascentistas, já encontraremos os primeiros esforços de concretizar uma verdadeira arte urbana. Mas um campo de estudos que começa a analisar a cidade como um espaço que corresponde a um viver próprio que é passível de ser estudado mais sistematicamente sob o ponto de vista das Ciências Sociais, aliás, em formação, eis aqui uma contribuição mais específica que só poderia ser trazida pelo século XIX, simultaneamente contra o pano de fundo dos novos saberes especializados que então surgiam e da própria centralidade que um mundo urbano em vias de se superpovoar passava a ocupar nos destinos humanos com a emergência das sociedades industriais. O próprio termo "urbanização" aparece em uma de suas primeiras formulações em 1860, proposto pelo arquiteto espanhol Ildelfonso Cerda. Ele é também o autor da primeira obra, nesse campo, que discute os desdobramentos sociais da industrialização, preocupando-se em elaborar uma Teoria Geral da Urbanização (1867). ${ }^{2}$

Para o afloramento desses vários interesses nos tempos modernos, contribuíram, como se disse, os acelerados processos de urbanização e industrialização. Foi diante desse novo mundo urbano que, ao mesmo tempo, o fascinava e o ameaçava (fenômeno que, por outro lado, ajudou a gestar a contrapartida romântica de uma literatura evasiva que apregoava o regresso à natureza) que o homem ocidental também se pôs a refletir cientificamente sobre a cidade. Buscava, talvez, compreender os problemas específicos desse habitat ao qual boa parte da humanidade parecia destinar-se. Queria refletir sobre a organização da vida citadina, sobre as origens imemoriais do fenômeno urbano, e sobre as formas históricas de urbanização; talvez na ânsia de legitimar aquela nova forma de urbanização à qual a sua civilização parecia estar cada vez mais confinada.

Para além disso, o século XIX trouxera novas lutas sociais, muitas das quais plenamente desenvolvidas nos meios urbanos. $O$ século dos primeiros impulsos acelerados de industrialização era também o das utopias, dos ideais revolucionários por diversas vezes traídos, das barricadas erguidas e destroçadas nos convulsionados ambientes urbanos europeus. Herdeiro dos sonhos iluministas e dos pesadelos revolucionários, da crença oitocentista no progresso e da sua adaptação a um mundo que não excluía grandes decepções, o século XIX gestara simultaneamente o
2. O Urbanismo seria fundamentado como disciplina independente alguns anos depois, com a obra StadtReweiterugem in Technischer, de Reinhard Maumister (1876). Mas, na verdade, a expressão "urbanismo", empregada como designativo desse novo campo do saber, aparece pela primeira vez em 1910, com o geógrafo francês Pierre Clerget.

Cadernos de Arquitetura e Urbanismo, v.18, n.22, $1^{0}$ sem. 2011 
positivismo e marxismo. Desejos de legitimar ou de transformar o novo mundo moderno, dentro do qual a cidade desempenhava um papel capital, produziam ambiguidades diversas, confrontações múltiplas, propostas de combinar uma atitude e outra.

Ainda vigorava amplamente, nos meios filosóficos e científicos, uma mentalidade evolucionista: o século XVIII fora o Século das Luzes, que muitos contemporâneos quiseram ver como a etapa maior na evolução da humanidade; mas seria o século XIX quem assistiria ao impacto das ideias de Charles Darwin acerca da Origem das espécies através da seleção natural (1859). No transplante das ideias do evolucionismo natural para o mundo humano, e sobre as cinzas da fênix iluminista, abria-se a possibilidade de se pensar a cidade como uma etapa mais avançada do desenvolvimento humano, ou até a cidade especificamente ocidental como uma forma mais evoluída de urbanismo para a qual deveriam convergir historicamente formas urbanas menos elaboradas. O urbanismo ocidental apresentava-se para muitos como modelo a ser alcançado por outras civilizações, o que desqualificava os modelos urbanos diferenciados das sociedades orientais. Essa perspectiva eivada de etnocentrismo começaria a ser questionada num futuro não muito distante, no seio da grande crise de descentramento que se abateria sobre o homem ocidental moderno no século XX. Mas, naqueles primeiros momentos da reflexão urbana, muitos passaram a enxergar a cidade como um destino ou até mesmo como uma etapa evolutiva.

Do mesmo modo, das mutações desencadeadas pela Revolução Francesa, começavam a emergir, naquele tempo, novas disposições estatais, um novo conceito de "nação", novos padrões de desenvolvimento institucional. Os intelectuais do século XIX eram conclamados a trabalhar para o Estado na montagem dos seus mecanismos institucionais fundamentais, na sua legitimação, na produção de sua memória. Florescem, a partir daí, as bibliotecas e arquivos, readaptam-se as antigas universidades, criam-se novas disciplinas e práticas acadêmicas. Era preciso também legitimar o mundo moderno, o mundo do capital (um mundo que encontrava na cidade a sua armadura mais adequada).

Na ânsia de encontrar uma racionalidade para esse complexo mundo que os próprios seres humanos criaram, desenvolvem-se novos campos, como o da "Economia Clássica", buscando formular racionalmente as leis de mercado e compreender os mecanismos de funcionamento do capitalismo. Marx parte da mesma preocupação de compreender o mundo do capital, mas por outro viés, e incorpora, na sua linha explicativa, a ideia da luta de classes, o compromisso com a mudança dialeticamente determinável e, por outro lado, a esperança de um mundo socialmente mais justo. Lança, por seu turno, as bases para uma reflexão sobre a relação dinâmica entre a cidade e o campo, e principalmente coloca a História no centro das possibilidades de compreender a trajetória e os destinos da humanidade.

É a partir desse contexto diversificado, abarcando pontos de vista e expectativas tão distintas e, no entanto, produtos do mesmo século de fascínios e decepções diante das possibilidades humanas e sociais, que se produziram as primeiras reflexões sobre a cidade no mundo moderno. 


\section{A análise institucional do fenômeno urbano}

Uma visão panorâmica sobre as obras produzidas no século XIX acerca do fenômeno urbano deixa entrever o cerne de suas principais preocupações. À parte, a contribuição de Karl Marx (1818-1873), que abre caminhos para uma análise da cidade em concomitância com aspectos sociais e históricos mais amplos (MARX, 1986) (embora ele mesmo não se detenha propriamente em uma reflexão isolada sobre o fenômeno urbano), e do próprio Engels (1820-1895), que chega a refletir sobre aspectos da psicologia e do cotidiano citadino (ENGELS, 1845), a grande preocupação dos estudiosos oitocentistas do fenômeno urbano é visivelmente relativa às suas bases institucionais.

Entre aqueles que refletiram sobre os aspectos institucionais da questão urbana no século XIX, alguns autores mostram uma tendência a entender a cidade não como um estado derivado da natureza, mas como uma parte da própria natureza. Procuram entender a origem da cidade com base na associação de agregados e células sociais básicas, como a família, ou outros agregados elementares que dariam origem às formações mais complexas que corresponderiam a instituições sociais mais complexas. Em perfeita conformidade com os interesses dos grandes Estados, que buscam legitimar nesse período as suas instituições mais específicas, para esses autores pioneiros, a cidade parece se constituir essencialmente, e por vezes até exclusivamente, em torno de instituições sociais.

A preocupação com as origens institucionais da cidade remete ao interesse de alguns historiadores oitocentistas ao estudo da Antiguidade. Não é à toa que surge, em 1864, a obra já clássica de Fustel de Coulanges, denominada A cidade Antiga (1924). Nesta, suas preocupações com vistas ao entendimento do fenômeno urbano são bastante explícitas: família, propriedade privada e religião.

Para Fustel de Coulanges (1924, p. 65), ${ }^{4}$ a cidade constitui-se em torno de instituições sociais.

Há três coisas que, desde a idade mais antiga, encontram-se solidamente fundadas e estabelecidas nas sociedades gregas e itálicas: a religião doméstica, a família, e o direito à propriedade; três coisas que tiveram entre si, na origem, uma relação manifesta e parecem ter sido inseparáveis.

Nessa linha de reflexões, Fustel de Coulanges foi um dos primeiros autores a chamar atenção para o papel da religião como um dos fundamentos da cidade. Afirma, por um lado, que a cidade formou-se a partir dos sucessivos agregados dessa célula primária que é a família.

Por outro lado, Fustel de Coulanges já chamava atenção para o fato de que teria sido o sentimento religioso o que levara os homens a estabelecerem relações de solidariedade.

O culto dos antepassados agrupou a família à volta de um altar. Daí a primeira religião, mas também a propriedade estabelecida, a ordem fixa da sucessão. Depois a crença alargou-se e, da mesma forma e ao mesmo tempo, a associação. Conforme os homens sentem que existem para
3. Também a "Segunda parte" de A ideologia alemã (MARX, 2000) contém desenvolvimentos significativos sobre a cidade.
4. Trechos citados da edição italiana: La città antica (Florença: Vallecchi, 1924).

Cadernos de Arquitetura e Urbanismo, v.18, n.22, $1^{0}$ sem. 2011 
eles divindades comuns, vão se unindo em grupos cada vez mais extensos. As mesmas regras encontradas e estabelecidas para a família aplicam-se sucessivamente à pátria, à tribo, à cidade (FUSTEL DE COULANGES, 1924, p. 165-166).

Esse primeiro modelo institucional de análise historiográfica sobre as origens e a natureza do fenômeno urbano teria sucessores no futuro, mesmo que introduzindo críticas às formulações de Fustel de Coulanges. Apenas para dar um exemplo do século seguinte, já marcado pela preocupação com o indivíduo, mas ainda alicerçado na preocupação com as instituições, tornaram-se notórias as críticas de Gustav Glotz ao historiador francês. Chega a criticar a metodologia aplicada por Fustel de Coulanges, que teria caminhado "sem sair do mesmo sítio, colocando a família no centro de uma série de círculos concêntricos" (GLOTZ, 1969).

A resposta de Glotz (1928) à busca das origens institucionais da cidade é outra. Por um lado, tem o mérito de tentar estabelecer um "modelo conflitual de evolução da cidade". Por outro, introduz o indivíduo como elemento ativo na constituição do fenômeno urbano.

Não são duas as forças que veremos em luta, a família e a cidade, mas três: a família, a cidade e o indivíduo. Cada uma delas foi se tornando sucessivamente predominante. No primeiro momento, a história das instituições é formada por famílias que conservam ciosamente o seu direito primordial e submetem todos os outros membros ao seu interesse coletivo; no segundo, a cidade subordina a si as famílias, chamando em sua ajuda os indivíduos libertados; no terceiro, os excessos do individualismo causam a ruína à cidade, a ponto de se tornar necessária a constituição de Estados mais vastos (GLOTZ, 1969).

Retornando àqueles que refletiram sobre a questão urbana no século XIX, podem ainda ser registradas outras obras marcadas pelas preocupações institucionais, muitas vezes ancoradas na vinculação profissional dos historiadores que as produziram às instituições estatais. Um exame da produção historiográfica sobre períodos específicos, como o Medieval ou o da modernidade do Antigo Regime, pode contribuir para dar uma ideia de como as investigações acerca de formações urbanas específicas encontram-se, no século XIX, penetradas de todos os lados por uma História predominantemente, senão exclusivamente, institucional.

Um exemplo típico é a obra historiográfica explicitamente institucional de Labande, denominada Histoire de Beauvais et de ses institutions communales (1892). A obra de Reinecke (1896) sobre a história da cidade de Cambrai mantém-se na mesma linha. São obras em geral minuciosas, descrevendo em detalhe as instituições citadinas e a organização municipal. Gregorovius, por seu turno, desenvolve uma minuciosa História da cidade de Roma na Idade Média em oito volumes. A preocupação com o sistema de propriedade aparece em G. Des Marez, com seu Étude sur la propriété foncière dans le ville du Moyen Age et spécialement en Flandre (1898).

Outro exemplo clássico, mas já de uma historiografia que, mesmo no início do século seguinte, perpetuava a tradicional reflexão institucional oitocentista, corresponde à famosa obra de Petit-Dutaillis: Les Communnes françaises, caractères et évolution, 
des origines au XVII siècle (1947). Chama atenção a preocupação de Petit-Dutaillis em definir a cidade como um agrupamento voltado para a gerência de interesses coletivos. Conforme se vê, a mesma linha de preocupações acionada por Fustel de Coulanges perpetua-se como o cerne da questão para muitas das obras que lhe seguiram no seu mesmo século ou mesmo na primeira metade do século XX. Por outro lado, esse novo século traria novas preocupações ao estudo da cidade em geral, e da cidade medieval em particular. Aparecem notadamente as preocupações com a função econômica, com o modo de vida do citadino, com a forma urbana e sua organização social, com a representação e com o imaginário da cidade, com as relações entre o público e o privado. A cidade já não será vista exclusivamente com base no modelo político-institucional.

Percebe-se, no conjunto de reflexões trazidas pelo século $X X$, que, na sua ânsia de captar a essência urbana, o sociólogo ou historiador havia passado a fabricar imagens diversas, consoante os critérios de análise priorizados. A cidade torna-se simultaneamente "artefato," "produto da terra", "ambiente", "sistema", "ecossistema", "máquina", "empresa," "obra de arte" ou mesmo um "texto" onde podem ser lidos os códigos mais amplos de sua sociedade. Desenvolvem-se novos conceitos. "Armadura" ou "rede urbana", a cidade revela a sua interação com as outras cidades, com o campo que a circunda, com o sistema estatal mais amplo.

Nuclear ou policêntrica, organismo em crescimento celular concêntrico ou em fatias triangulares, a cidade deve ser vista também em termos da população citadina que ela abriga. Haveria uma cultura urbana, ou uma caracterologia fundamental do citadino? Ou a cidade abre-se para uma miríade de subculturas urbanas? As questões perdem-se no infinito... São talvez os indícios de uma nova tendência a enxergar a cidade por uma multiplicidade de aspectos e que, no decurso do século XX, passa a instigar nos sociólogos e historiadores as mais variadas imagens para uma aproximação do fenômeno urbano. Reconhecer essas diversificadas bases imaginárias a partir das quais se lança o estudioso, nos seus esforços de perceber o fenômeno urbano, constituirá um ponto de partida particularmente interessante para construir um panorama sobre a reflexão urbana no século XX.

\section{As Ciências Humanas e as novas metáforas urbanas do século $\mathrm{XX}$}

Diante dos múltiplos aspectos urbanos que foram trazidos à tona pela Historiografia e pela Sociologia do século XX, uma pergunta se impõe. O que vem a ser, afinal, a cidade? Na sua ânsia de responder a essa questão, os homens ligados aos diversos campos de saber e às mais variadas atividades humanas têm produzido metáforas diversas; entre esses homens, o poeta, o pintor, o homem comum e também o cientista social. Mesmo sem perceber, e por vezes acreditando-se liberto dos recursos metafóricos que os homens da literatura e da arte têm o direito de empregar mais livremente, a verdade é que o pensamento do cientista moderno também opera por modelos, frequentemente espacializados. 
Não há nada de grave nisso. As metáforas de altura têm sido de longa monta empregadas para expressar níveis diferenciados de hierarquia social (o emprego da palavra "níveis" constitui, já em si mesmo, uma metáfora espacial). As metáforas (espaciais) de "centralidade" e "periferia" são imperceptivelmente empregadas para tornar claras determinadas relações de poder. A metáfora da "rede" recobre interações e relacionamentos sociais diversos. A Informática, por exemplo, sempre empregou, sem nenhuma crise de consciência, padrões similares de organização mental. Os usuários que estabelecem contatos via internet "navegam na rede", e em nenhum momento isso prejudica nem a objetividade nem a intersubjetividade de suas relações interativas.

Por outro lado, a metáfora empregada (a forma externa mediante a qual se expressa ou se constitui determinado pensamento) também ajuda a reformular esse mesmo pensamento, a reconduzi-lo para uma determinada direção mental sem que nem sempre o seu usuário disso se aperceba.

No que concerne ao esforço de compreensão do fenômeno urbano, diversas imagens têm sido empregadas desde tempos imemoriais, cada qual acarretando em benefícios e limitações, e o mesmo ocorreria com o conhecimento produzido sobre a cidade no século XX. A metáfora do ímã, por exemplo, tem sido particularmente simpática aos economistas contemporâneos e aos demógrafos. Polo de atração, a cidade absorve homens e mercados. ${ }^{5}$ Por outro lado, o "poder magnético" das cidades remete às noções de centro e periferia, particularmente no que concerne à região a elas adstritas. Dessa forma, o geógrafo $R$. E. Dickinson (1961), que também trabalhou interdisciplinarmente com a História (1952), observa que "cada centro age como se fosse um ponto focal, situado na confluência de vias e correntes de tráfego por meio das quais se liga à área circundante que constitui o seu corpo de associação" (DICKINSON, 1961; 1952).

Assim, a cidade estabelece relações com o campo circundante, mas também com outras cidades. Noções como "retículo urbano" e "armadura urbana" têm sido empregadas para dar conta de todo um conjunto de determinadas cidades pertencentes a uma mesma área geográfica (MERCADAL, 1971). Já o conceito de dominância metropolitana procura dar conta "do poder político-econômico de algumas cidades relativamente ao resto do território entendido como um sistema social global" (BOGUE, 1949).

Por outro lado, para fugir à linearidade que a noção "centro-periferia" pode evocar, Sorokin e Zimmerman (1929) elaboram o conceito de continuum urbano-rural, na ânsia de dar forma à dinamicidade de relações existentes entre as duas realidades. No campo do aspecto da dinamicidade, também se acham as imagens que procuram enfatizar a dimensão da cidade como lugar privilegiado para as trocas. Assim, para Fernando Braudel (1997a, p. 439), "As cidades são como transformadores elétricos: aumentam as tensões, precipitam as trocas, caldeiam constantemente a vida dos homens."6

Conforme se vê, as imagens e metáforas empregadas pelos cientistas sociais carregam já dentro de si certas potencialidades e limitações que devem ser manejadas com vistas a determinadas finalidades, ou em função da constituição de determinados obje-
5. Atentando para o paradoxo deste "poder magnético da cidade", Paul Goodman (1970) critica a tese de que a urbanização seja decorrência natural do desenvolvimento tecnológico: "É como se, por força de uma lei - a metáfora preferida é a da cidade como ímã - 75\% dos americanos devessem viver em 1990 em densas áreas metropolitanas. E, ao contrário disso, não é de modo nenhum verdade que a urbanização seja uma necessidade técnica. Pelo contrário, o impulso da tecnologia contemporânea - isto é, a eletricidade, novas fontes de energia, automóveis, comunicações de longa distância e automatização - vai em direção da desurbanização, do descentramento quer da população quer da indústria. Esse era o pensamento de Marx e Engels [...] de Kropotkine, Geldes, F. L. Wright, e de tantos outros entusiastas da tecnologia científica. A verdade é que a urbanização não fica a dever-se a causas tecnológicas, ou naturais ou sociopsicológicas, mas a uma economia e a uma política que não tomam em linha de conta os custos sociais" (GOODMAN, 1970, p. 16).

6. Sobre a análise braudeliana do fenômeno urbano, ver BRAUDEL, Fernando. As cidades (1997a, p. 439-514).

Cadernos de Arquitetura e Utrbanismo, v18, n.22, $1^{0}$ sem. 2011 
tos. Conforme se produzem novos métodos, novas abordagens ou novas perspectivas dentro de cada disciplina, uma nova imagem pode emergir ou uma antiga metáfora pode ser revalorizada.

\section{A cidade como artefato e como produto da terra}

Já se disse que a cidade, mesmo que não seja o maior artefato produzido pelo homem, é, sem dúvida, o mais grandiosamente impactante. Ainda que, em sua estrutura física, nenhuma cidade seja tão imensa quanto a Muralha da China, ou que um sistema urbano específico esteja longe de ter a abrangência espacial e social de um sistema de telefonia com seus infindáveis fios que recobrem espaços incomensuráveis, uma cidade é seguramente o maior artefato produzido pelo homem que pode ser apreendido a determinada distância pelo olhar contemplativo. Witold Rybczynski (1995) observa que, enquanto uma rede de telefonia é um imenso artefato que permanece relativamente invisível para os homens, a cidade deve muito de seu poderoso impacto no imaginário social ao atributo de poder ser contemplada em toda a sua grandeza e totalidade pelo olho humano, desde que tomada a devida distância. ${ }^{7}$ A cidade, nesse sentido, seria o maior artefato produzido pelo homem que pode ser integralmente apreendido pelo olhar comum.

Uma questão importante, relacionada a esse aspecto, é a das formas que pode assumir o artefato urbano na sua própria origem, pelos seus modos de funcionamento, pelos seus padrões de transformação. Essas questões, a serem discutidas mais adiante, permanecem indelevelmente ligadas. De imediato, é bom lembrar que uma determinada imagem do que seja ou deva ser a cidade pode estar implicada na sua própria formação primordial e nas suas subsequentes transformações. Os próprios homens que se unem para constituir uma cidade já começam a interferir nos seus destinos formais nos primeiros instantes, valendo-se das suas próprias imagens. São essas imagens que o cientista social (ele mesmo um formador de imagens) deve examinar em um primeiro momento.

Kelvin Lynch classifica as cidades em três categorias básicas com relação aos seus padrões formais, de funcionamento e transformação. Haveria as "cidades cósmicas", que são aquelas cujos traçados são concebidos em função de algum sentido mítico, de algum padrão de espacialização imposto de fora por alguma ideia matriz, ou de algum desenho preconcebido consoante uma representação específica. Nessa categoria, estariam desde as antigas cidades etruscas e indianas, cujo traçado é concebido para atender a algum padrão religioso ou místico, até as modernas cidades, como Brasília, que seguem um plano-piloto prenhe de significados. As "cidades cósmicas" podem ser lidas de fora, porque o seu traçado carrega explicitamente uma mensagem carregada de intencionalidades. Elas foram feitas para significar algo para o observador que as contempla de uma distância a partir da qual o traçado pode ser percebido na sua totalidade.

Haveria também as "cidades práticas." A imagem que mais se adapta a esse tipo de cidades é a da "máquina", ou do artefato mecânico. São cidades que crescem e se desenvolvem conforme as suas ne-
7. "O sistema telefônico é imenso, mas invisível, e apenas uma parte da Grande Muralha ou do Canal do Panamá podem ser vistos de uma vez; a imensidão dessas invenções faz com que elas só sejam apreendidas pela imaginação. Mas uma cidade pode ser vista inteira de uma vez. Daí por que as vistas panorâmicas sejam tão emocionantes" (RIBCZYNSKI, 1995, p. 33). 
cessidades materiais, conforme novas partes são acrescentadas e as velhas são alteradas. O padrão de transformação associado a esse tipo é o da superposição de um tipo mais ou menos mecânico.

Existiriam, por fim, as chamadas "cidades orgânicas", que são aquelas que vão se formando e crescendo mais ou menos à maneira dos organismos vivos, adaptando-se a um terreno em que se viram inseridas de maneira não planejada, e sobretudo fazendo concessões permanentes à vida em toda a sua imprevisibilidade. Essas cidades modificam os seus traçados para se adaptarem a um rio que thes serve de fronteira, contornam os morros ou os absorvem, sobem e descem ladeiras de variados tamanhos. Suas ruas organizam-se livremente para atender mais aos chamados da vida cotidiana que aos planejamentos previamente estabelecidos. As cidades medievais constituem exemplos muito típicos de "cidades orgânicas" e também as pequenas cidades mineiras do Brasil colonial, como Ouro Preto. Da Idade Média também nos chegam os exemplos das cidades labirínticas que são tão comuns em algumas das sociedades islâmicas, com suas ruelas e becos que se perdem uns nos outros e que desorientam quem não conhece o padrão vital que está por trás de sua aparente desorganização.

$\mathrm{O}$ artefato urbano também pode ser examinado consoante a sua relação de abertura ou de fechamento para com o mundo externo (abertura ou fechamento que pode ou não se explicitar no plano físico mais imediato). O historiador Fernando Braudel examinou essas tendências urbanas de abertura ou fechamento com base em um estudo da sua historicidade, identificando padrões mais ou menos recorrentes para cada período com respeito a esse tipo de relação. Para ele, as cidades poderiam ser, grosso modo, classificadas em "cidades abertas", "cidades fechadas" e "cidades sob tutela" (BRAUDEL, 1997b, p. 471-477).

As cidades antigas tenderiam para o modelo aberto, em oposição ao modelo explicitamente fechado das cidades medievais. A muralha que costumava cercar estas últimas seria apenas a parte mais visível de um sistema urbano fechado que também implicaria em um fechamento político e econômico.

A partir do século $X V$, com a formação dos sistemas políticos centralizados, surgiria o modelo das "cidades dominadas", submetidas fundamentalmente a um controle que lhes é externo (como, por exemplo, a centralização estatal). À parte, uma visível imposição do poder institucional na arquitetura dessas cidades, consolidando-se em grandes avenidas e praças, a "cidade dominada" teria produzido uma sensível mudança no sentido de cidadania: enquanto primordialmente a cidadania havia implicado uma ligação com a cidade, como no caso das cidades antigas e medievais, agora ser cidadão passaria a remeter a uma ligação com o Estado.

No século XIX, as cidades industriais parecem se fechar novamente, embora não mais fisicamente, sendo notável que cada vez se torna mais clara a oposição entre o rural e o urbano a partir de uma fronteira muito definida. A partir da cidade pós-industrial do final do século XX, acrescenta Ribczynski (1995) em um comentário sobre a esquematização anteriormente proposta por Braudel, parece ressurgir uma tendência para o modelo da cidade aberta da Antiguidade. Nesse caso, a diferença ou a separação física entre a cidade e os seus subúrbios passaria a ser mais difusa. 
O artefato urbano, conforme se vê, tende a se mostrar aberto ou fechado conforme o seu contexto histórico. Como diversas das cidades costumam atravessar os tempos históricos, costuma ocorrer também uma espécie de superposição de padrões de espacialidade aberta e fechada em um mesmo espaço urbano. Também ocorre que uma cidade conserve os seus muros medievais, mas esses já não correspondam mais a uma prática de fechamento em relação ao mundo exterior. Nesses casos, o artefato perde algumas de suas funções primordiais e, quem sabe, adquire outras. A muralha que antes servia para a defesa e que constituía, nos tempos medievais, a resistente armadura de um "artefato bélico" torna-se, nos tempos modernos, a principal atração de um "artefato turístico", pronto não mais para repelir, mas sim para seduzir o visitante que, com as suas máquinas fotográficas, para ela corre.

Encarar a cidade como "artefato" pode ter as suas vantagens, mas também traz consigo os seus eventuais limites. Os arqueólogos mais antigos, com bastante frequência, encaravam a cidade como um artefato a ser recuperado, e não raro como um grande recipiente a ser analisado meramente nos seus aspectos físicos mais imediatos. Ora, a cidade é, na contrapartida, "uma forma que adquire conteúdos variáveis" (RONCAYOLO, 1986, p. 398). Estudar a forma separada do seu conteúdo é sinal de uma nem sempre adequada "divisão do trabalho intelectual", essa que se torna cada vez mais insustentável diante dos parâmetros da interdisciplinaridade que invadem diversos campos do saber científico.

Gordon Childe (1950) é talvez o primeiro arqueólogo a libertar-se do tipo de modelo "artefato" mediante o qual os arqueólogos de seu tempo costumavam conceber a cidade, talvez aprisionados por uma leitura arqueológica demasiado específica. Procura desenvolver, ao contrário, uma visão global da cidade e não apenas uma análise linear das suas construções e artefatos. É já um arqueólogo no sentido mais moderno: historiador da cultura material que revolve o artefato urbano para decifrar a sociedade nos seus múltiplos aspectos, e que se vale de conhecimentos interdisciplinares para enxergar a cidade mais como sistema do que como artefato arquitetônico.

Mas a cidade é também um produto da terra. Existe por obra de um excedente agrícola sem o qual seria inconcebível na sua formação mais remota (MUMFORD, 1938). ${ }^{8}$ Enxergar a cidade como produto da terra é direcionar o olhar para um aspecto bastante específico de suas origens: cidade simultaneamente povoada por homens provenientes dos campos circundantes e mantida pela produção daqueles que permaneceram no ambiente rural. Produto da terra e obra do homem do campo; não seria essa, certamente, a metáfora empregada pelos defensores das origens exclusivamente comerciais das cidades da Idade Média (Henri Pirenne, 1962 [original: 1927].

O já mencionado modelo da cidade como "artefato" abre espaço para um outro: o da cidade como artefato esteticamente construído. Ou, dito de outra forma, o da cidade como obra de arte. A cidade, que certamente inclui dentro de si muitos e muitos objetos e produtos artísticos, passa a ser vista aqui, na sua inteireza, como um objeto artístico ela mesma (ARGAN, 1995, p. 73).
8. "As cidades são um produto da terra. Refletem a sagacidade do camponês ao dominar a terra; tecnicamente, apenas prolongam a sua habilidade em dar ao solo empregos produtivos, em resguardar-lhe o gado com segurança, em regular as águas que irrigam os seus campos, em fornecer silos e celeiros para as suas colheitas. As cidades são a representação dessa vida estável que começa na agricultura permanente: uma vida que se vive com o auxílio de abrigos permanentes, de utilidades permanentes tais como pomares, vinhedos e obras de irrigação, e de edificações permanentes para proteção e armazenagem" (MUMFORD, 1961, p. 13). Texto original de 1938.

Cadernos de Arquitetura e Urbanismo, v.18, n.22, $1^{0}$ sem. 2011 
Essa nova metáfora desdobra-se, por um lado, na possibilidade de enxergar a cidade obra de arte coletiva, reelaborada permanentemente tanto pelos seus eternos construtores como pelos seus diversos habitantes. Por outro lado, a metáfora aponta também para a possibilidade de examinar a cidade como obra de arte dos urbanistas. Esta última perspectiva vem já das últimas décadas do século XIX e tem um de seus marcos no livro de Camillo Sitte (1843-1903), que foi intitulado A construção da cidade segundo seus princípios artísticos (1889). O seu modelo era o da cidade culturalista, que se opunha radicalmente ao urbanismo geométrico e utilitário e que passava a privilegiar precisamente a cidade que abre espaço para a imprevisibilidade estética, mas também atentando para a necessidade de assegurar um ambiente que fosse favorável à saúde psicológica de seus habitantes.

Esse mesmo modelo de urbanismo culturalista teve continuidade nos anos seguintes, por meio das obras do urbanista e estenógrafo inglês Ebenezer Howard (1850-1928), que foi o grande idealizador das chamadas "cidades-jardins". Essas foram por ele apresentadas como modelo ideal no livro Cidades-Jardins de Amanhã, publicado em 1898 com outro nome até sua reimpressão em 1904 (HOWARD, 2003). Sua ideia era combinar a vocação dinâmica da cidade com a beleza e saúde da vida no campo. A mesma ideia apareceria em diversos urbanistas do século XX, preocupados em unir em uma única realidade esses dois universos aparentemente tão contraditórios, que são a cidade propriamente dita e o campo.

Aparece também em Ebenezer Howard a preocupação com o crescimento desenfreado da população urbana, que tanto afligiria os urbanistas do século XX, sobretudo a partir da intensificação da explosão demográfica, a partir da década de 1950. A solução de Howard para o problema era a de que o crescimento populacional urbano produzisse sempre a fundação de novas cidades equivalentes, e nunca o inchaço populacional que tem sido tão característico das últimas metrópoles no último século.

A apreensão do fenômeno urbano com base em imagens diversificadas apresenta indefinidas soluções. Quantas outras imagens são possíveis! Ao lado da cidade-jardim, concebe-se a cidade como empresa ou como indústria. ${ }^{9}$ Ao lado da cidade "obra de arte", afirma-se a cidade como registro concreto e quase imperecível da memória humana. Ou, por fim, a cidade pode ser lida como um texto que registra as atitudes de uma sociedade perante os fatos mais elementares de sua existência. Vale a pena, contudo, examinar um outro circuito de imagens que foi muito importante para o pensamento do século XX sobre a cidade: o circuito de imagens orgânicas e naturais.

\section{Os modelos biológicos e ecológicos}

Se a cidade pôde ser compreendida por alguns arqueólogos e urbanistas como um artefato, não faltaram estudiosos que consideraram esse modelo inadequado para a expressão daquilo que há de vivo e de mutável nessa formação social específica. Buscando reagir à ideia de enxergar a cidade como mero recipiente, não deixaram de surgir também os modelos biológicos diversificados. ${ }^{10}$
9. Mais ou menos na mesma época em que urbanistas culturalistas como Camillo Sitte (Der Stadtbau, 1889) e Ebenezer Howard idealizam as cidades esteticamente concebidas e os modelos ecológicos das cidades-jardins, surgem também os urbanistas progressistas, que passam a conceber a cidade de uma perspectiva predominantemente industrial. A obra que inaugura esse novo caminho nas concepções urbanas é A cidade industrial (1917), de Tony Garnier (1869-1948). Mais tarde, em 1919, seria fundada, sob a direção do arquiteto alemão Walter Gropius, a Bauhaus, escola de arquitetura que se tornaria o centro formação do Urbanismo progressista, impulsionando-o em novas direções.

10. "A Escola de Chicago, pelo contrário, sustentava que a cidade não era apenas um artefato, mas, num certo sentido, em alguns graus, um organismo" (PIZZORNO, 1987, p. XVIII). Deve-se acrescentar ainda que, ao lado dos sociólogos da Escola de Chicago, a própria associação entre cidade e realidade biológica já havia sido iniciada pelos próprios estudiosos oriundos do campo da Biologia. Assim, Patrick Geddes (1994), biólogo escocês, já havia publicado, em 1915, um livro intitulado Cidades em evolução.

Cadernos de Arquitetura e Urbanismo, v.18, n.22, $1^{0}$ sem. 2011 
Os modelos biológicos utilizados para a compreensão das cidades e dos processos de crescimento urbano remetem a duas vertentes. De um lado, a comparação da cidade com um organismo vivo, seja um organismo complexo formado por vários órgãos que desempenham funções diversas, seja a célula, notando-se que esse modelo é frequentemente utilizado para a visualização dos processos de crescimento urbano. De outro lado, a cidade pode ser enquadrada como ambiente ecológico, uma vez concebida a ecologia como um estudo dos seres vivos em relação com o seu ambiente. Assim, esse último modelo abarca a interação dos seres vivos não apenas uns com os outros, mas também a sua interação com o ambiente inorgânico.

Tanto uma como outra vertente dos "modelos biológicos" implicam trazer para o vocabulário das Ciências Humanas uma série de palavras e expressões que, a princípio, estiveram vinculadas às Ciências Naturais. Hoje, essas palavras já são de uso corrente para a expressão de fenômenos sociais, particularmente os relacionados ao âmbito urbano. Dentre as expressões herdadas da terminologia clássica, que passou a examinar a cidade como um organismo, destacam-se noções como "crescimento", "tecido", "artéria", "coração", "função". Veremos, contudo, que o empréstimo dos modelos naturais para a compreensão do fenômeno urbano tem uma história remota e que alguns sociólogos do século XX apenas resgatam um modo já de pensar a cidade já tradicional, embora o adaptando a necessidades inteiramente novas.

Não eram raras na Antiguidade as comparações da cidade a um grande ser. A Bíblia nos mostra os tradicionais exemplos de comparação da cidade de Jerusalém com a noiva de Cristo, ou da Babilônia como a Grande Prostituta. Mais tarde, no Período Medieval, em nítida referência bíblica, o cronista português Fernão Lopes não hesitaria em comparar a cidade de Lisboa à noiva do Mestre de Avis. Mas as possibilidades vão além: comparar a cidade ao ser vivo abre-se à possibilidade de visualizar a cidade como um corpo constituído por diversos órgãos.

Esse tipo de metáfora corporativa da cidade remete fundamentalmente à Idade Média. Um dos exemplos mais notórios é a descrição do "corpo citadino" por João de Salisbury, parisiense do século XIII, na obra Policraticus. Para ele, cada grupo social estaria fadado a desempenhar uma função específica. Os mercadores, por exemplo, de acordo com o entendimento de Salisbury, seriam equivalentes ao "estômago da sociedade", e, no seu aspecto negativo, arriscariam transmudar-se em um órgão desmesuradamente guloso. ${ }^{11}$ Avaliando o posicionamento desse cronista e teórico medieval, o historiador Walter Ullmann (1980) interpreta a utilização da metáfora do corpo em Salisbury como um desejo de "imobilização do indivíduo na sociedade" e de sua fixação por trabalho ou função. No contraponto dessa concepção medieval do corpo citadino, quanto mais elevada fosse a função de um indivíduo, mais influência, mais riqueza e mais direitos the seriam atribuídos.

A metáfora da cidade como corpo presta-se, como se vê, a propósitos explicitamente funcionais. Não é à toa que, por ocasião da emergência do positivismo comtiano no século XIX, que buscava legitimar e privilegiar o papel de uma burguesia industrial como órgão diretivo da sociedade, ressurjam metáforas com-
11. "Se eles saciam a sua voracidade e continuam insatisfeitos, provocam o crescimento de incontáveis e incuráveis doenças [...] podem através de seus vícios provocar a ruína do corpo inteiro" (SALISBURY, 1990, p.45).

Cadernos de Arquitetura e Urbanismo, v.18, n.22, $1^{0}$ sem. 2011 
parando as camadas dirigentes ao cérebro e o operariado, aos braços e pernas. Modificadas em diversos aspectos, algumas dessas ideias em torno das funções sociais seriam levadas para o século XX por Émile Durkheim (1962). ${ }^{12}$

Por outro lado, mesmo antes de Augusto Comte, Saint-Simon, que fora mentor do jovem positivista na fase inicial de sua carreira, já havia utilizado o modelo biológico. Com Saint-Simon, porém, o modelo do organismo social fora utilizado para um propósito diametralmente oposto, buscando criticar radicalmente o poder preestabelecido ao assinalar a ideia de que algumas classes, como o clero e a aristocracia, seriam como que "parasitas do organismo social". Mesmo Marx (2008) embora mais como recurso estilístico do que como modelo de análise, visualizara a antiga sociedade como prenhe da nova sociedade, a quem não poderia dar à luz sem passar pelas dores revolucionárias do parto. Para a reforma ou para a revolução, os modelos naturalizados da sociedade começavam a invadir gradualmente a imaginação sociológica.

Por outro lado, o século XIX trouxera também a "atitude evolutiva". Diversos pensadores no Ocidente já vinham, desde o Século das Luzes, elaborando a ideia de "progresso do desenvolvimento humano", tendendo a imaginar a civilização ocidental como uma etapa superior a ser alcançada por todas as sociedades. Por outro lado, Charles Darwin formulara, no campo das ciências naturais, a sua teoria da Evolução das Espécies (1859). Com ela, além de reforçar a ideia de um plano evolutivo identificável na própria natureza, introduzira novos conceitos (como o de "competição natural") que não tardariam a ser reapropriados pelas Ciências Humanas. ${ }^{13}$ É também com base em Charles Darwin que E. Haeckel (1834-1919) formula as bases para um novo campo do saber, a "ecologia", considerando-o como o "Estudo da economia e do modo de habitar dos organismos animais, incluindo-se as relações dos animais com o ambiente inorgânico e toda a intrincada série de relações à quais Darwin se referiu falando de condições da luta pela existência" (HAECKEL, 1868, p.354).

Ora, esse desenvolvimento significativo no campo das ciências naturais e da ecologia, bem como essa retomada de modelos naturais pelos sociólogos oitocentistas para expressar relações diversas do universo humano não têm propriamente uma repercussão imediata no campo dos estudos urbanísticos que lhes foram contemporâneos, pelo menos no que concerne à formulação de modelos para visualizar a cidade. Já vimos que a preocupação dos historiadores oitocentistas da cidade fora sobretudo com os aspectos institucionais, o que se deve em parte a uma demanda pelos seus serviços da parte dos governos estatais que buscavam se reorganizar no novo quadro europeu pós-napoleônico. A cidade como uma grande família, como um grande agrupamento de células institucionais básicas, ou, enfim, como uma grande instituição; esse fora o modelo instrumentalizado pelos historiadores das instituições municipais e dos Estados nacionais reorganizados, e também daqueles poucos que se aventuraram a refletir sobre as origens do fenômeno urbano.

Mas já começava a gestar-se algo novo em termos de visualização do fenômeno urbano, que só daria seus principais frutos
12. "Há, certamente, circunstâncias nas quais muitas funções econômicas entram em concorrência. No organismo individual, a seguir a um jejum prolongado, o sistema nervoso nutre-se com prejuízo dos outros órgãos, e o mesmo fenômeno produzse se a atividade cerebral atinge um desenvolvimento demasiado considerável. O mesmo acontece na sociedade nas épocas de carestia ou de crise econômica. As funções vitais são obrigadas, para subsistir, a privar dos seus meios de sustento as funções menos essenciais" (DURKHEIM, 1962, p. 270-271)

13. Também Marx não ficaria à parte das teorias evolucionistas. Em Contribuição à crítica da economia política (2008, p.4550), ele escreve: "A anatomia do homem é a chave da anatomia do macaco. $\mathrm{O}$ que nas espécies animais inferiores indica uma forma superior não pode, ao contrário, ser compreendido senão quando se conhece a forma superior. A economia burguesa fornece a chave da Economia da Antiguidade" (MARX, 2008, p,47). O evolucionismo darwiniano estende também a sua sombra sobre a visão de mundo do fundador do socialismo científico.

Cadernos de Arquitetura e Urbanismo, v.18, n.22, $1^{0}$ sem. 2011 
nas primeiras décadas do século XX. A teoria da evolução, os primórdios da ecologia, por um lado, e a "livre competição" da economia clássica, com a contrapartida socialista que trazia à tona as inquietações sociais e retomava a noção de "luta de classes", por outro, começava ma fermentar aí uma nova imaginação sociológica, pronta a ser catalisada por uma renovada aceleração industrial trazida pelas primeiras décadas do século XX.

É todo esse conjunto de ideias que precede à formulação de uma "ecologia urbana" na década de 1920, devendo-se acrescentar que também por essa época os biólogos começam a desvendar os segredos da "célula" e a inteirar-se a respeito de seus processos de crescimento. Ao mesmo tempo, enquanto a Europa recuperava-se da Primeira Guerra Mundial, os Estados Unidos começavam a despontar como um novo palco para a repensagem do fenômeno urbano na Modernidade. Diante de toda uma massa de informações que envolviam desde o estudo da ecologia até os mecanismos mercadológicos examinados com base na ótica do liberalismo econômico e diante da ânsia de formular novos modelos para a compreensão do funcionamento e das disfunções da cidade, um grupo de sociólogos especializados nos estudos urbanos estabelece, na Chicago da década de 1920, o novo campo da "ecologia urbana". Por eles, a cidade será considerada, a partir de então, como "o habitat natural do homem".

"A cidade é uma constelação de áreas naturais, cada uma delas com o seu ambiente característico e a sua função específica no conjunto da economia urbana". Foi com essas palavras que Ezra Park (1929) definiu a cidade em um famoso artigo intitulado $A$ cidade como um laboratório social, no qual buscava sintetizar algumas das suas ideias acerca do fenômeno urbano.

A definição é particularmente interessante por ressaltar dois aspectos fundamentais do pensamento ecológico desse que foi um dos fundadores Escola de Chicago. Por um lado, Park fala-nos em "áreas naturais", remetendo-nos a um diálogo com a Ecologia que não hesitará em trazer para o plano sociológico noções como "estímulo", "mobilidade," "caráter patológico", "competição", "simbiose". Por outro lado, o sociólogo americano também nos fala de funções específicas para essas que seriam as "áreas naturais" da formação urbana.

Park fora discípulo de Simmel, que instigara na geração da Escola de Chicago o interesse pela "mobilidade social" e pela psicologia do homem urbano. ${ }^{14}$ Mas também fora profundo conhecedor da obra de Durkheim, daí retirando a preocupação com as funções sociais. Explica a formação daquilo que chamou de "áreas naturais" por intermédio do "princípio da comunicação" e do "princípio da competição", neste último particular, notando-se um certo darwinismo social que muitos criticariam em alguns dos escritos produzidos pela Escola de Chicago. Com base no princípio da competição, a distribuição da população tende a selecionar e agrupar conjuntamente os semelhantes. Dessa forma, seria da relação dialética entre "competição" e "comunicação" que seriam geradas, sempre por processos de ajustamento, as "áreas naturais".

A obra fundadora da Escola de Chicago é a publicação coletiva denominada The City (1925), na qual aparecem textos de Park, Bur-
14. Em 1916, Robert Ezra Park já havia escrito um artigo na linha de Simmel, que se intitulava A cidade: sugestões para a investigação do comportamento humano no ambiente urbano. Esse artigo, que integrou mais tarde a obra coletiva The City (1925, p.1-46), já prenuncia a linha de pesquisas que marcaria a Escola de Chicago a partir de 1925.

Cadernos de Arquitetura e Urbanismo, v.18, n.22, $1^{0}$ sem. 2011 
gess, Mckenzie e Wirth, entre outros. Sua principal contribuição é a constituição de um novo modelo de visualização da cidade, que os próprios membros da Escola de Chicago procuraram entender como um novo campo do conhecimento. A "ecologia humana", dessa forma, é definida por Mckenzie, no livro de 1925, como "a ciência que se ocupa dos aspectos espaciais, das relações simbióticas de seres e de instituições conforme estejam empenhados nas forças seletivas, distributivas e adaptadoras do ambiente físico".

Deve-se entender, antes de tudo, que a Escola de Chicago foi um grupo de pesquisas efetivo, em que cada um recebeu certas funções voltadas para a preocupação de abarcar a totalidade dos aspectos urbanos. Burgess, por exemplo, foi encarregado de estabelecer um modelo generalizável para o crescimento das "áreas naturais". Wirth estudou os aspectos da "mobilidade", da "desorganização social", da caracteriologia do citadino e, por outro lado, da formação de subculturas urbanas. Voltados para uma miríade de aspectos associados ao fenômeno urbano, o modelo da cidade como o lugar natural do homem assumia múltiplas formas, emprestadas às comunidades simbióticas de seres vivos, às colmeias, às células em crescimento e multiplicação, aos ecossistemas, aos modelos do corpo e do organismo vivo com sua divisão funcional em uma diversidade de órgãos; era um vasto campo de imagens que se abria a partir desses pensamentos iniciais.

O modelo ecológico suscitou reflexões diversificadas no mundo inteiro, em muitos aspectos, distintas e até críticas em relação à Escola de Chicago. No Leste Europeu, surgiu, por exemplo, uma abordagem que alguns autores denominaram "ecológico-funcionalista", e que teve em Jiril Musil um de seus principais representantes. Por outro lado, o modelo do "ambiente ecológico" foi eventualmente utilizado por pesquisadores nem sempre vinculados às habituais escolas ecológicas. Lewis Mumford (1991), autor de uma história da cidade que se tornou referência obrigatória para os estudos de história do urbanismo ocidental, compara a cidade (via de regra, como recurso estilístico) ao corpo humano ou a outros elementos naturais, como a "árvore". É bastante citar um comentário do autor referente ao processo mediante o qual a cidade medieval, apesar de sua origem exclusivamente feudal, logo se torna palco para uma luta entre dois sistemas concorrentes: "Ao proporcionar um ninho no qual o cuco do capitalismo podia depositar seus ovos, a cidade murada em breve permitiu que os seus próprios rebentos fossem postos para fora pelo atrevido forasteiro que abrigara" (MUMFORD, 1991, p. 282).

Nada mais "ecológico" do ponto de vista de certos desenvolvimentos típicos da Escola de Chicago. As metáforas pertencem ao mundo natural; os fundamentos de organização e controle espacial são a concorrência e a "seleção natural"; e o ambiente urbano é perfeitamente assimilado ao "habitat natural" do homem.

\section{A cidade entendida como um sistema}

A cidade também tem sido modernamente compreendida (ou visualizada) como um sistema. Mas que tipo de sistema? Eis aqui uma nova pergunta que se abre a múltiplas respostas. Isard (1942) a considerou como "sistema circulatório", e os membros da Escola 
de Chicago a assimilaram a um "sistema ecológico." Mas a cidade também pode ser encarada como um sistema no sentido informático, abrindo-se ainda aqui múltiplas possibilidades conforme a definição do modelo de interação para os seus vários elementos. Um famoso artigo do arquiteto e matemático Christopher Alexander (1965) poderá nos servir para elucidar essa questão.

Intitulado "A cidade não é uma árvore", o texto do arquiteto vienense recebeu o prêmio de melhor artigo do ano de 1965 no campo do design (ALEXANDER, 1965). O autor defende a tese da superposição dos subsistemas de vida urbana, propondo superar os modelos reducionistas e esquemáticos de compreensão da cidade (por ele chamados de "estruturas em árvore") em favor de modelos que captem a verdadeira complexidade urbana ("estruturas em grelha").

O artigo de Alexander objetiva, a princípio, contribuir para uma nova maneira de pensar a cidade, imprescindível aos urbanistas que pretendam projetar ou criar novas cidades sem perder aspectos da "cidade natural." De nossa parte, acreditamos que o modelo de compreensão proposto pelo urbanista vienense seja também útil para a compreensão da natureza intrínseca das cidades já existentes e de sua complexidade, que às vezes se vê reduzida e comprometida por esquemas simplificadores.

Alexander distingue, inicialmente, dois modos de pensar que coincidem com modelos de representação de estruturas de conjuntos. A "árvore" corresponde a uma estrutura ramificada que o homem utiliza toda vez que pensa na esquematização ou na abstração de uma estrutura. A "estrutura em grelha" corresponde ao modelo proposto pelo autor.

Para exemplificar, considere uma cidade hipotética. Existe uma esquina onde se localiza um bar com uma banca de jornais em frente. No cruzamento diante da esquina, existe um sinal de trânsito. Quando este se abre para o tráfego, o pedestre para na calçada e aproveita para ler superficialmente as notícias e informações dos jornais e revistas. Outros se habituam a tomar diariamente um café no bar em frente. Semáforo, calçada, transeuntes, jornaleiro, banca de jornais e bar são elementos que formam um "conjunto". Uma vez que esses elementos interagem, o conjunto é chamado de "sistema"; um sistema efetivamente significativo para diversos cidadãos.

Numa cidade, existe uma infinidade desses pequenos sistemas, que por isso são chamados de "subsistemas." A vida urbana de uma cidade utiliza uma parte dos subsistemas disponíveis na cidade. Os subsistemas significativos para cada cidadão se integram, superpondo-se. Cada elemento de um subsistema pode pertencer a outro subsistema, consistindo nisso a riqueza da vida urbana.

Ora, é precisamente essas superposição e riqueza que se perdem nos modelos de compreensão habituais, fundados na "estrutura de árvore". Imaginam-se os elementos separados, contíguos, mas não superpostos. Dessa forma, acaba-se separando os elementos de uma unidade, esquematizando um modelo de cidade que não corresponde em absoluto à sua vida urbana.

Em projetos urbanísticos, isso corresponderia a planejar zonas de funções estanques, distribuições rígidas de equipamento, 
isolamento da recreação, sem prever, em momento algum, uma integração efetiva de seus elementos. Em análise sociológica ou historiográfica, acrescentaríamos por nossa conta, isso corresponde a repartir as cidades já conhecidas em compartimentos e subsistemas não integrados, sacrificando a compreensão da verdadeira vida social que aí se desenrola. Ou seja, apesar de a vida urbana corresponder a uma "estrutura de semigrelha", estabelece-se uma "estrutura de árvore" para facilitar a ação de pensar.

Uma coleção de conjuntos constitui uma "semigrelha" somente quando dois de seus conjuntos se superpõem e o conjunto de elementos comuns a ambos também pertencem à coleção. No exemplo antes mencionado, isso corresponderia a dizer que existe um conjunto "sinal de trânsito - banca de jornais" e outro conjunto "banca de jornais - bar"; a "banca de jornais" é uma unidade que também pertence à coleção. De forma contrária à "estrutura de grelha", a "árvore" define-se como a coleção em que, para cada dois conjuntos, ou um está inteiramente contido no outro ou estão totalmente separados.

Estendendo, por nossa conta, a reflexão de Alexander para as análises sociológica e historiográfica, deve-se evitar o risco de isolar estruturas sociais e vizinhanças também em compartimentos estanques. A família $X$ tem vínculos de amizade com a família $Y$, pertençam ou não à mesma unidade de vizinhança, ou mesmo a grupos sociais diferentes. Em uma cidade moderna, por exemplo, os filhos vão a uma escola de outro bairro porque lá parece haver professores melhores, e as compras mais importantes podem ser feitas em um supermercado mais afastado em virtude de preços melhores. Em cidades medievais, existem mesmo ambientes ou ocasiões que pressupõem o contato entre grupos sociais diferenciados, apesar de toda a compartimentação prefigurada pela hierarquização ou pela setorização corporativa das sociedades urbanas medievais.

Isso não quer dizer que não se devam estudar os mecanismos de segregação social ou a compartimentação urbana, que apresentam efetivamente diversas formas consoantes às várias sociedades e períodos históricos. Significa apenas que não se devem desprezar os aspectos que transformam a cidade em um grande sistema integrado. A proposta de Alexander, conforme se vê, é integralizar nesse novo modelo urbano a teoria dos conjuntos e da informática, com vistas a obter novas visões objetivas da complexa realidade citadina e da integração dos seus subsistemas, além de forçar a compreensão da natureza psicológica e social da vida urbana para encontrar os princípios ordenadores de uma cidade.

\section{A cidade como texto}

Outra imagem da cidade que permitiu uma renovação radical nos estudos dos fenômenos urbanos foi a da "cidade como texto". Essa imagem ergue-se sobre a contribuição dos estudos semióticos para a compreensão do fenômeno urbano, sobretudo a partir do século XX. Segundo essa perspectiva, a cidade pode ser também encarada como um "texto", e o seu leitor privilegiado seria o habitante (ou o visitante) que se desloca através da cidade, seja nas suas atividades cotidianas para o caso do 
habitante já estabelecido, seja nas atividades excepcionais, para o caso dos turistas e também do habitante que se desloca para um espaço que the é pouco habitual no interior de sua própria cidade. Em seu deslocamento, e em sua assimilação da paisagem urbana por meio de um olhar específico, esse citadino estaria permanentemente sintonizado com um gesto de decifrar a cidade, como um leitor que decifra um texto ou uma escrita. Podemos aqui retomar as palavras de Roland Barthes (2001, p. 224): "A cidade é um discurso, e esse discurso é verdadeiramente uma linguagem: a cidade fala a seus habitantes, falamos nossa cidade, a cidade em que nos encontramos, habitando-a simplesmente, percorrendo-a, olhando-a".

A seus habitantes e, por extensão, a seus analistas, uma cidade fala eloquentemente dos critérios de segregação presentes em sua sociedade por meio dos múltiplos compartimentos em que se divide, dos seus acessos e interditos, da materialização do preconceito e da hierarquia social em espaço. Sua paisagem fala de sua tecnologia, de sua produção material; seus monumentos e seus pontos simbólicos falam da vida mental dos que nela habitam e daqueles que a visitam; seus caminhos e seu trânsito falam das mais diversas atividades que no seu interior se produzem; seus mendigos falam da distribuição de sua riqueza ao estender a mão em busca de esmolas. Cada um desses índices remete às letras de um alfabeto que pode ser pacientemente decifrado pelos sociólogos, pelos historiadores, pelos urbanistas. A cidade, sem dúvida, pode ser "lida", e é nessa perspectiva que se têm colocado alguns estudiosos do urbanismo a partir de meados do século XX.

A aplicabilidade da metáfora da "escrita" à cidade tem, certamente, diversos sentidos. Existe, por exemplo, a escrita produzida pelo desenho das ruas, monumentos e habitações; em duas palavras: a escrita arquitetônica de uma cidade. Trata-se de uma escrita sincrônica, que nos fala daqueles que a habitam, e também de uma escrita diacrônica, que nos permite decifrar a "história" da cidade que é lida. A cidade, em muitos casos, vai superpondo temporalidades, permitindo que habitações mais antigas convivam com as mais modernas. Em outros casos, ela faz desfilar as temporalidades sucessivamente, quando deslocamos nossa leitura através de bairros que vão passando de uma materialidade herdada de tempos antigos a uma materialidade mais moderna, nos bairros onde predominam as construções recentes.

É também importante notar que os próprios habitantes vão reescrevendo a escrita de sua cidade permanentemente. Por vezes imperceptível na passagem de um dia a outro, esse deslocamento da escrita urbana deixa-se registrar e entrever na longa duração. Os prédios que, em uma época, eram continentes da riqueza e símbolos do poder, podem passar nessa longa duração a continentes da pobreza e a símbolos da marginalidade. Os casarões do século XIX, que eram habitações de ricos, degeneram-se ou deterioram-se em cortiços, passando a abrigar dezenas de famílias mal acomodadas e a configurar espaços habitacionais marginalizados. Nessa passagem marcada pela deterioração do rico palacete em cortiço miserável, deteriora-se também a imagem externa do bairro e o seu valor imobiliário, de modo que o espaço que um dia configurou uma "área nobre" passa, em tempos posteriores, a configurar uma zona marginalizada do ponto de vista imobiliário. 
Esse "deslocamento social do espaço" também acaba por se constituir em uma forma de escrita que pode ser decifrada. As motivações para esse deslocamento podem ser lidas pelo historiador: a história da deterioração de um bairro pode revelar a mudança de um eixo econômico ou cultural, uma reorientação no tecido urbano que tornou periférico o que foi um dia central ou um ponto de passagem importante.

Enfim, de múltiplas maneiras, o próprio espaço e a materialidade de uma cidade se convertem em narradores da sua história. Diante dessa percepção da cidade como uma escrita que tem algo a dizer, surgiu concomitantemente um esforço de conservação do patrimônio arquitetônico que encontra uma de suas expressões nos tombamentos históricos. Os monumentos e as construções antigas passam a ser considerados, nesses casos, como registros da memória coletiva. Fragmentos de textos, enfim, que a comunidade ou aqueles que ela designou para representá-los não desejam ver apagados no processo de incessante reescrita do texto urbano.

Do que vimos até aqui, a imagem de uma cidade-texto traz consigo uma dupla implicação. Um texto pode ser definido como algo passível de ser lido, mas também pode ser compreendido como algo que é escrito. Daí que, se os cientistas sociais que examinam a cidade tomam esse texto apenas na sua dimensão de objeto de leitura, já os seus habitantes e os passantes que a percorrem no dia a dia podem se relacionar ao texto-cidade simultaneamente do ponto de vista da leitura e da escrita. Kevin Lynch, em um texto originalmente escrito em 1960, já fazia notar, referindo-se às pessoas que circulam dentro da cidade e que constituem a sua parte humana, que estas não são meros observadores do espetáculo urbano, mas parte dele (LYNCH, 1999, p. 2). Os pedestres podem ler o texto urbano, mas eles também o reescrevem e, de algum modo, podem ser mesmo considerados como alguns dos personagens ou dos caracteres móveis que fazem parte da construção desse texto urbano. Essa tríplice relação do pedestre com o texto urbano (como leitor, como escritor, como personagem de sua narrativa ou, o que vem a dar no mesmo, letra móvel do seu alfabeto infinito) merece ser discutida em pormenor.

Discutiremos, para melhor iluminar a questão proposta, a "ideia afim" de que a cidade é comparável a um enunciado linguístico (o que remete, dessa maneira, não apenas ao texto escrito, mas também ao texto falado). Roland Barthes (2001), em um texto originalmente escrito em 1970, e, em seguida, Michel de Certeau (2002), fazem notar que, se a cidade constitui uma "ordem espacial" que pode ser comparada à língua, por outro lado, os pedestres que caminham por essa ordem espacial atualizam e reinventam essa língua. Por isso, se a ordem espacial urbana é como uma língua, com suas possibilidades e proibições, a caminhada através dessa ordem urbana (a "enunciação pedestre" nos dizeres de Certeau) é equivalente ao ato de enunciar (CERTEAU, 2002, p. 177).

Ao caminhar pela cidade, cada pedestre apropria-se de um sistema topográfico (de maneira análoga ao modo como um locutor apropria-se da língua que utilizará) e, ao mesmo tempo, realiza esse sistema topográfico em uma trajetória específica (como o falante que, ao enunciar a palavra, realiza sonoramente a língua). 
Por fim, ao caminhar em um universo urbano, onde muitos outros caminham, o pedestre insere-se em uma rede de discursos: um sistema polifônico de enunciados, partilhado por diversas vozes que interagem entre si (como se dá com os locutores que se colocam em uma rede de comunicações, tendo-se na mais simples "conversa" um dos exemplos mais evidentes).

Enfim, se existe um sistema urbano (com a sua materialidade e com as suas formas, com as suas possibilidades e os seus interditos, com as suas avenidas e muros, com os seus espaços de comunicação e os seus recantos de segregação, com os seus códigos de trânsito) existem também os modos de usar esse sistema. A metáfora linguística do universo urbano aqui se sofistica: existe a língua a ser decifrada (o texto ou o contexto urbano), mas existe também o modo como os falantes (os pedestres e habitantes urbanos) utilizam e atualizam essa língua, inclusive criando, dentro desse mesmo sistema de língua, as suas comunidades linguísticas particulares (dentro da cidade, existem inúmeros guetos, inúmeros saberes, inúmeras maneiras de circular na cidade e de se apropriar dos vários objetos urbanos que são partilhadas por grupos distintos de indivíduos).

É extremamente difícil e desafiador para o historiador que estuda as realidades urbanas do passado recuperar o registro dessas caminhadas (ou desses "atos de fala" dos enunciadores urbanos). A dificuldade está em que não se trata apenas de recuperar os caminhos possíveis ou percorríveis por meio das várias atividades cotidianas. Se a cidade é um texto que pode ser lido a partir da materialidade urbana e se é possível imaginar os pedestres do passado que percorriam esse texto em pontilhado (ou seja, que realizavam percursos), é preciso lembrar que o ato de caminhar através de uma cidade é uma operação complexa que envolve muitos outros gestos e sentidos para além do movimento das pernas e do deslocamento no espaço. Quem caminha observa a paisagem, vivencia possibilidades e interditos, vai ao encontro ou foge do encontro de outros passantes, segrega ou é segregado. Um pedestre nas cidades modernas caminha observando vitrines, decodificando sinais de trânsito, administrando liberdades e inseguranças. O pedestre das cidades de todas as épocas acelera e desacelera os seus passos, vivencia emoções olfativas e táteis, respira o ar de sua cidade. Muitos desses gestos e sentidos perdem-se para o historiador que contempla apenas a planta de uma cidade ou que tenta adivinhar na materialidade urbana de hoje o que foi a vida dos homens que a habitaram no passado.

É preciso, portanto, não apenas recuperar os traçados dos múltiplos percursos, como também identificar as diversas maneiras de caminhar; não apenas inventariar os lugares, como analisar as maneiras de se apropriar dos lugares.

Uma última implicação da metáfora da cidade como texto ou como discurso é a de que o complexo discurso urbano aloja dentro de si diversos discursos de todas as ordens. A cidade também fala aos seus habitantes e aos seus visitantes por meio dos nomes próprios que ela abriga: dos nomes de ruas, de edifícios, de monumentos. O grande texto urbano aloja dentro de si textos menores, feitos de placas de ruas que evocam memórias e imaginários, de cartazes que são expostos nas avenidas para 
seduzir e informar, de sinais de trânsito que marcam o ritmo da alternância entre a passagem permitida e os interditos aos deslocamentos no espaço. A cidade é um grande texto que tece dentro de si uma miríade de outros textos, inclusive os das pequenas conversas produzidas nos encontros cotidianos.

Eis aí, enfim, a aventura que se abre aos pesquisadores que se aproximam da cidade com base na metáfora linguística ou apoiando-se na imagem da cidade como texto: ele se torna um decifrador de discursos e de relações geradas com base numa multiplicidade de discursos.

\section{Considerações finais}

Este texto fundamentou-se na ideia de que o cientista social, o historiador e os demais estudiosos dos fenômenos e das estruturas urbanas nos diversos campos do saber, algumas vezes, constituem o seu objeto de estudo baseados em determinadas imagens da cidade ou de modelos singulares para a sua compreensão. Imagens e modelos que terminam por produzir, no fim das contas, expectativas e perspectivas específicas, que acabam por permitir ou favorecer determinadas metodologias conforme a imagem a partir da qual o estudioso se aproxima do fenômeno urbano. A título de balanço final, a figura 1 oferece um esquema simplificado, registrando as imagens urbanas que foram discutidas neste artigo, sendo necessário acrescentar que muitas outras imagens poderiam ser evocadas na mesma medida.

A imagem da qual parte o estudioso de fenômenos urbanos, ou a imagem de base que fundamenta a sua percepção de cidade, frequentemente conduz a análise a uma determinada direção e não a outra, assim como permite examinar aspectos que, de outra forma, poderiam passar despercebidos. Analisar a cidade é já enxergá-la de uma determinada maneira, iluminar certos fatores e não outros, estruturar certas formas de concebê-la em detrimento de outras. A reflexão sobre a cidade no decurso dos séculos XIX e XX, e até nossos dias, conforme tivemos oportunidade de verificar, oferece fartos exemplos de modelos construídos sobre imagens específicas: a cidade como organismo, artefato, recipiente, ambiente ecológico, texto, sistema, obra de arte coletiva, entre outras imagens possíveis.

A possibilidade de articular imagem ou modelo (ou de perceber que o modelo é em alguns momentos o produto de uma determinada imagem que orienta certo modo de ver) recoloca a questão do imaginário científico como um aspecto importante a ser compreendido quando se trata de balancear a produção bibliográfica existente sobre a cidade. O cientista social, tal como aventamos nesse texto, frequentemente fabrica as suas próprias imagens acerca do fenômeno analisado, e, no caso dos estudos urbanos, essa assertiva tem se mostrado especialmente relevante, uma vez que aqui abundam os modelos de cidade claramente amparados em imagens específicas. Resta dizer, por fim, que a imagem ou modelo utilizado também tende a favorecer determinadas formas de expressão e de constituição do texto final destinado a expor os resultados do trabalho e da reflexão do pesquisador. Daí a importância de se compreender os modelos e imagens de que dispõem habitualmente os 


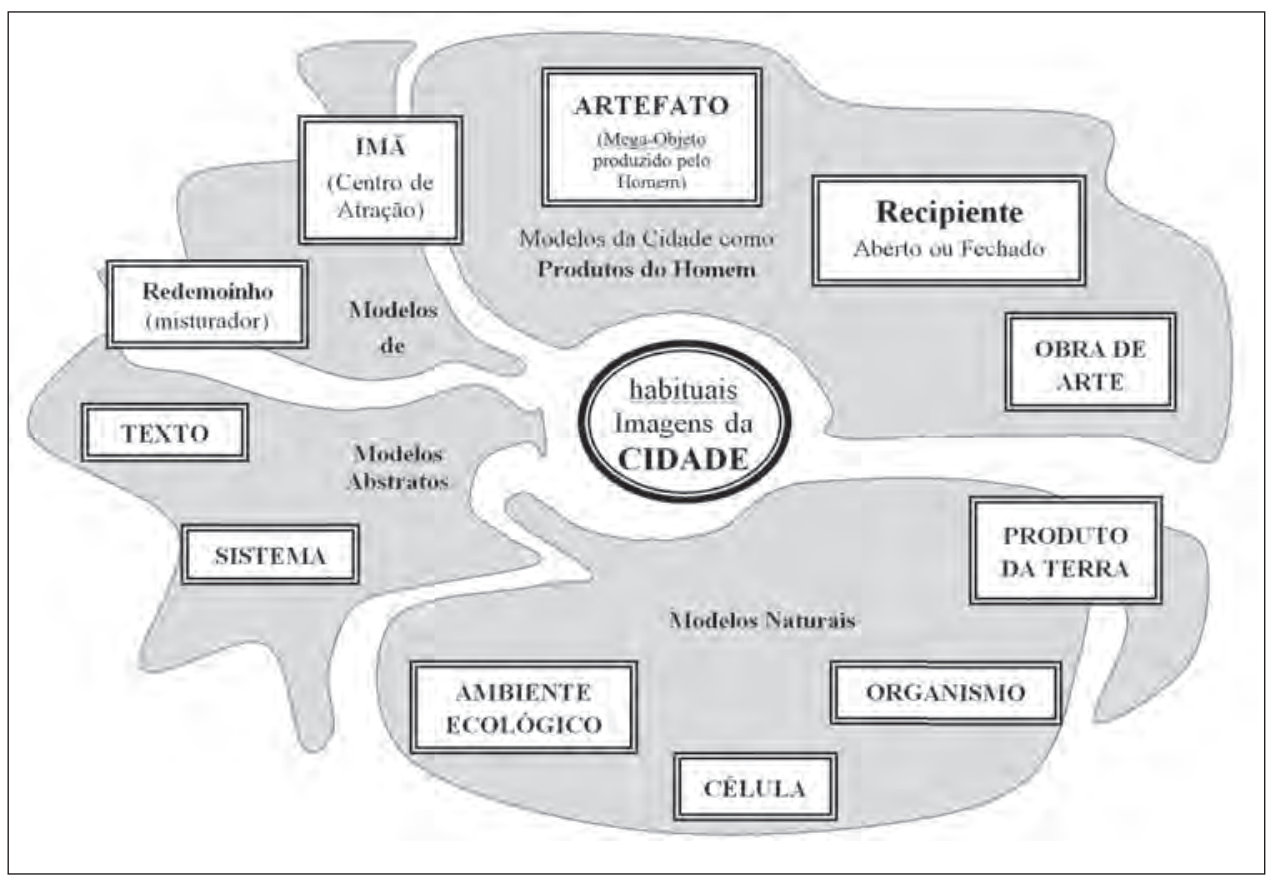

cientistas sociais para visualizar a cidade. É no momento em que se coloca plenamente consciente das imagens que estará pronto a empregar na produção de seu saber, que o cientista social e o historiador se capacitam para avaliar as formações urbanas de um ponto de vista multifuncional e multifatorial, ou para se aperceberem meIhor das possibilidades complexas do seu estudo. Avançar nessa complexidade multifatorial é precisamente um desdobramento dessa tomada de consciência. A cidade é um fenômeno complexo, aberto a diversificadas leituras, e, ao pesquisador, inspira diversas imagens de si mesma.

\section{Referências}

ALEXANDER, Christopher. A cidade não é uma árvore. Architectural Forum, vol.122, nº 1, abril de 1965, pp. 58-62.

ARGAN, Giulio Carlo. História da arte como história da cidade. São Paulo: Companhia das Letras, 1995.

BARTHES, Roland. Semiologia e urbanismo. In: BARTHES, Roland. A aventura semiológica. São Paulo: Martins Fontes, 2001, p.114-128.

BAUMISTER, Reinhard. Stadterweiterungen in technischer, baupolizeilicher und wirthschaftlicher Beziehung. Berlin: Ernst \& Korn, 1876.

BRAUDEL, Fernand. As cidades. In: BRAUDEL, Fernand. Civilização material, economia e capitalismo. (v. 1). São Paulo: Martins Fontes, 1997a, p. 439-514.

BRAUDEL, Fernando. As formas urbanas do Ocidente aceitam um "modelo"? In: BRAUDEL, Fernando. Civilização material, economia e capitalismo. (v. 1). São Paulo: Martins Fontes, 1997b, p. 471-477.
Figura 1 - Imagens da cidade nas Ciências Sociais e Humanas. 
BOGUE, D. J. The Structure of the Metropolitan Comunity: A Study of Dominance and Subdominance. Michigan: Ann Arbol, 1949.

CERTEAU, Michel de. A invenção do cotidiano, 1: a arte de fazer. Petrópolis: Vozes, 2002.

CHILDE, V. Gordon. The Urban Revolution. Town Planning Review, vol.XXI, n¹, 1950, p.3-17.

CLERGET, Pierre. L'urbanisme, étude historique, géographique et économique. Bulletin de la Société neuchâteloise de géographie, $n^{\circ} 20,1910$. p.213-231.

DICKINSON, Richard. E. City Region and Regionalism. London: Routledge \& Kegan Paul, 1952.

DICKINSON, Richard. E. The West European city: a geographical interpretation. London: Routledge and Kegan Paul, 1961.

DURKHEIM, Émile. The rules of the sociological method. Glencoe, III.: Free Press, 1962.

ENGELS, Friedrich A situação da classe operária na Inglaterra (1845). São Paulo: Boitempo, 2007.

FUSTEL DE COULANGES, N. D. A cidade antiga (1864). Florença: Vallecchi, 1924.

GARNIER, Tony. Une cité industrielle: étude pour la construction des villes. Paris: August Vicent, 1917.

GEDDES, Patrick. Cidades em evolução. Campinas: Papirus, 1994.

GLOTZ, Gustave. The Greek city and its institutions. London: Routledge and Kegan, 1969.

GOODMAN, Paul e Percival. Communitas. New York: Basic Books, 1970.

GREGOROVIUS, Ferdinand. A. Der Stadt Rom im Mittelalter. Stuttgart: J. G. Cotta, 1859-1872.

HAECKEL. Ernst. Natürliche Schöpfungsgeschichte. Berlin: G. Reimer, 1868.

HOWARD, Ebenezer. A peaceful path to real reform. London: Routledge and Kegan, 2003.

ISARD, Walter. Transport development and building cicles. Quarterly Journal of Economicy, 57, n¹, p.90-112, November, 1942.

LABANDE, León-Honoré. Histoire de Beauvais et de ses institutions communales. Paris: Imprimiere Nationale, 1892.

LYNCH, Kevin. A imagem da cidade. São Paulo: Martins Fontes, 1999.

MAREZ, Jean des. Étude sur la propriété foncière dans le ville du Moyen Age et spécialement en Flandre. GAND: Engelcke, 1898.

MARX, Karl. A ideologia alemã. São Paulo: Martins Fontes, 2000.

MARX, Karl. Formações econômicas pré-capitalistas. Rio de Janeiro: Paz e Terra, 1986.

MARX, Karl. Contribuição à crítica da economia política. São Paulo: Expressão Popular, 2008.

MERCADAL, Georges. Peut-on tirer un enseignement des es- 
sais français de modelisation du dévelopment spatial urbain?. Revue écononique, XXIII, 1971, p.952-991.

MUMFORD, Lewis. A cidade na História. São Paulo: Martins Fontes, 1991.

MUMFORD, Lewis. A cultura das cidades (1938). São Paulo: Editora Itatiaia, 1961

PARK, Robert. e BURGESS, E. Watson, (orgs). The City. Chicago: University of Chicago Press, 1925.

Park, Robert. (1925) "The City: Suggestions for the Investigation of Human Behavior in the Urban Environment" In: PARK, Robert. e BURGESS, E. Watson, (orgs). The City. Chicago: University of Chicago Press, 1925, p.1-46

PARK, Robert. "The City as Social Laboratory" In: SMITH, T.V. \& WHITE, L.D. (orgs). Chicago: An Experiment in Social Science Research. Chicago: University of Chicago Press, 1929, p.1-19.

PETIT-DUTAILLIS. Les Communes françaises, caractères et évolution, des origines au XVII siècle. Paris: Albin-Michel, 1947. PIRENNE, Henri. As cidades na Idade Média (1927). Lisboa: Europa-América, 1962.

PIZZORNO, A. Allessandro: introduzione. In: PARK, Robert E. La città. Milano: Edizioni di comunità, 1987, p.9 a 127.

REINECKE, Wilhelm. Geschichte der Stadt Cambrai. Marburgo: Elwert, 1896.

RIBCZYNSKI, Witold. O tamanho de uma cidade. In: RIBCZYNSKI, Witold. Vida nas cidades: expectativas urbanas no Novo Mundo. Rio de Janeiro: Record, 1995, p.9-32.

RONCAYOLO, Marcel. Cidade. In: Enciclopédia Einaudi. Região. (v. 8). Lisboa: Imprensa Nacional, 1986, p. 398.

SALISBURY, João de. Policraticus. Cambridge: Cambridge University Press, 1990.

SITTE, Camillo. Der Städtbau nach seinen kunstlerischen Grundsatzen. Viena: Springer Verlag, 1899.

SOROKIN e ZIMMERMAN. Principles of Rural-Urban Continuum. Harvard: 1929.

ULLMANN, Walter. John of Salisbury's Policraticus in the Later Middle Ages. In: ULLMANN, Walter. Jurisprudence in the Middle Ages. London: Variorum Reprints, 1980, p.519-545.

\section{Endereço para correspondência}

José D'Assunção Barros

Rua Engenheiro Ernani Cotrim, 155, apto.102

20510-260 - Rio de Janeiro-RJ

E-mail: jose.assun@globo.com 